\title{
A Need of Agricultural Students at King Mongkut's Institute of Technology Ladkrabang for Developing u-Learning based on Flipped Classroom Concept
}

\author{
Kulachai Kultawanich $^{1}$ and Nutthakorn Songkram ${ }^{2}$ \\ ${ }^{1}$ Lecturer, PhD, Department of Agricultural Development and Resources Management, \\ King Mongkut's Institute of Technology Ladkrabang, Thailand \\ ${ }^{2}$ Assistant Professor, PhD, Department of Agricultural Development and Resources Management, \\ King Mongkut's Institute of Technology Ladkrabang / Thailand
}

\begin{abstract}
Ubiquitous learning (u-Learning) has become the replacement of e-Learning. Since the mobile devices become a part of student's life. A lot of attention is drawn to u-Learning, which allow students access to the learning environment from any device platform. This paper aims to assess the needs of Agricultural students toward the u-Learning Model based on flipped classroom concept and studying the feasibility of the u-Learning model. This research is based on a survey developed on a sample of 274 students from 3 department in the faculty of Agricultural technology, King Mongkut's Institute of Technology Ladkrabang (KMITL). The relevant results of the study show that: the most of participants preferred to use mobile and laptop more than PC and tablet, while the flipped classroom pedagogy was suitable for the students.
\end{abstract}

Keywords: u-Learning, Need Assessment, Undergraduate, Flipped Classroom, Agricultural Student

\section{Introduction}

In recent years there has been a significant change in the awareness of many institute to utilize ICT in learning, especially in e-learning and m-learning. This phenomenon is an important factor of gradually developing communication technology and online learning innovation in this era. "u-Learning" is the learning platform developed to support learning activities with the goal of enhance students' learning in anytime, anywhere, and anyway (Cárdenas-Robledo and Peña-Ayala, 2018). Many researchers defined the element of ulearning very broad and variety, so after the reviews we conclude the element of u-learning as follows: 1) Lecturer/Facilitator, 2) Teaching Approach, 3) Communications, 4) Instructional Content, and 5) Technology. (Tsai, Tsai, and Hwang, 2011; Inthachot, Sopeerak, and Rapai, 2013; de Sousa Monteiro, Gomes and Mendes Neto, 2016)

A pedagogical approach that mostly implement into the classroom in recent years is "Flipped classroom", the method of teaching that reduce lecturing time, thus freeing class time for meaningful learning activities (Lombardini, Lakkala and Muukkonen, 2018). A flipped classroom is a key element of blended learning that inverted the traditional classroom by delivering instructional content especially online video through the learning platform, outside of the classroom. The u-Learning can support flipped classroom by letting students interact with class material, usually e-book or lecture videos on the learning system or submitting their works and then using class time to do the learning activities that require a lot of support from lecturer such as brainstorming, discussion, or debates (Sojayapan and Khlaisang, 2018). The u-learning platform can be used for students to explore, share, and create content via any internet ready device. 
The Faculty of Agricultural Technology open the learning programs to produce the scientist, communicator, and staff in agriculture, divided the structure into 3 departments (Agricultural Development and Resources Management, Animal Production Technology and Fishery, and Plant Production Technology). According to the vision from president of King Mongkut's Institute of Technology Ladkrabang aims to apply the ICT to enhance quality of active learning activities into every program, so the need assessment of undergraduate agricultural students was conducted, to find the suitable solution for developing u-learning based on flipped classroom concept. This paper aims to present the needs of agricultural students to the u-learning from the survey using closed end questionnaire.

\section{Conceptual Framework}

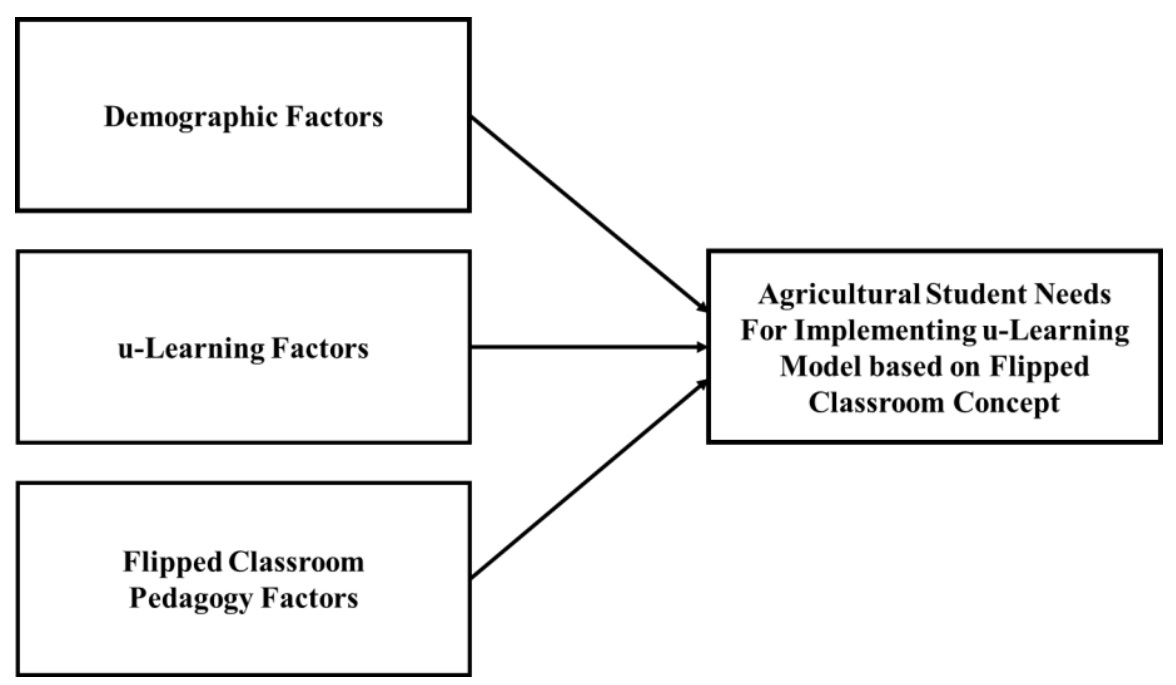

Fig. 1: Conceptual Framework

\section{Purpose of the Study}

1) To identify the factors that related with u-learning and flipped classroom.

2) To identify the need of agricultural students for implementing u-learning based on flipped classroom.

\section{Methodology}

\subsection{Participants}

The population of this research were 2,261 undergraduate students in King Mongkut's Institute of Technology Ladkrabang, Faculty of Agricultural Technology on academic year 2017. The number of participants were calculated by using a power analysis in G*Power Application (Faul, Erdfelder, Lang, and Buchner, 2007) with medium effect size (0.25), $\alpha=0.5,(1-\beta)=0.95$ and set the testing group to 3 (separated by number of the department in faculty) which 252 participants were required. We send out 100 questionnaires to each department in faculty of agricultural technology. The participant of this research were 274 students (101 males and 173 females) who completely fill the questionnaire. All participants were students in department of Agricultural Technology Faculty as follows: Agricultural Development and Resources Management Department $(\mathrm{N}=85)$, Animal Production Technology and Fishery Department $(\mathrm{N}=96)$ and Plant Production Technology Department $(\mathrm{N}=93)$. Almost half of participant are second year $(\mathrm{N}=109), 89$ - third year, 52 - first year and 24 - fourth year students. 


\subsection{Questionnaire}

The questionnaire for collecting the data in this study consisted of 32 questions divided into 3 sections as follows: 1) demographic information, 2) u-learning need assessment, and 3) students' opinion toward the flipped classroom pedagogy, as shown on TABLE I.

TABLE I: The structure of questionnaire

\begin{tabular}{|c|c|c|}
\hline \multirow{2}{*}{ Section } & \multicolumn{1}{|c|}{ Items } & $\begin{array}{c}\text { Number of } \\
\text { Questions }\end{array}$ \\
\hline 1. & Demographic Information & 1 \\
& 1.1 Gender & 1 \\
& 1.2 Department & 1 \\
& 1.3 Class Year & 3 \\
\hline 2. & u-Learning Need Assessment & \\
& 2.1 Lecturer & 5 \\
& 2.2 Teaching Approach & 5 \\
& 2.3 Instructional Content and Communication & 2 \\
\hline 3. & 2.4 Technology & 6 \\
\hline
\end{tabular}

\subsection{Data Collecting Procedure}

The researcher uses close ended questionnaire sending to participants. The procedures for collecting quantitative data are as follows:

1) Reviewing the information about u-learning, flipped classroom and gathering the factors to construct the structure of the questionnaire that can be used with context of agricultural students. Then building questions from the structure.

2) Validating the questionnaire using Item Objective Congruence Index (IOC) from 5 experts (IOC $=0.98$ ). Then develop the questionnaire.

3) Testing the reliability of the questionnaire with 30 students using Cronbach's alpha ( $\alpha=0.927)$.

4) Gathering the data from the participants by sending 100 questionnaires to each department in Faculty of Agricultural Technology. The researcher gets 274 filled up questionnaires.

5) Analyzing the data from the questionnaire.

6) Summarizing the results.

\section{Summary}

\subsection{1 Results and Discussions}

The result of this study can be summarised as follows:

1) Most of the participant owned a Smartphone $(\mathrm{N}=244,89.05 \%)$ and Laptop $(\mathrm{N}=206,75.18 \%)$ while Tablet $(\mathrm{N}=26,9.49 \%)$ and $\mathrm{PC}(\mathrm{N}=82,29.93 \%)$ are less preferred device among the students. According to the result, the u-learning system should design an interface based on laptop and mobile usage.

2) Most of the participant preferred the study time at night, during 6 p.m. -11.59 p.m. $(\mathrm{N}=153,55.80 \%)$ and 12.00 p.m. -5.59 a.m. $(\mathrm{N}=80,29.20 \%)$ while studying at daytime are less preferred, during 12.00 a.m. 5.59 p.m. $(\mathrm{N}=28,10.20 \%)$ and 6.00 a.m. -11.59 a.m. $(\mathrm{N}=13,4.70 \%)$, so the result indicated that most of students preferred to learn outside the school time that suitable for applying flipped classroom pedagogy. 
3) The result of Priority Need Index (PNI) analysis of agricultural students toward the Faculty's readiness for conduct the u-learning based on flipped classroom concept, found that there are 9 critical items (PNI >0.2) out of 20 items, that need to be improve before implementing u-learning. These items have been ordered and summarised into the TABLE II as follows:

TABLE II: The u-learning need assessment result.

\begin{tabular}{|c|c|c|}
\hline No. & Items & PNI \\
\hline 1. & The wifi hotspot and internet connection are enough for student usage. & 0.33 \\
\hline 2. & Student can choose to study anytime, anywhere. & 0.24 \\
\hline 3. & $\begin{array}{l}\text { Lecturer use different teaching method to enhance personal learning of the } \\
\text { student. }\end{array}$ & 0.23 \\
\hline 4. & Student can access to the internet resources anytime. & 0.23 \\
\hline 5. & Student was assigned to watch the learning material before enter class. & 0.22 \\
\hline 6. & Student can personally learn the preferred lesson. & 0.22 \\
\hline 7. & Lecturer usually recorded their lecture into a video. & 0.21 \\
\hline 8. & Lecturer provide the learning materials that student can review their lessons. & 0.21 \\
\hline 9. & Student can collaboratively discuss together in learning activities. & 0.20 \\
\hline 10. & Lecturer motivated the student to create an innovation. & 0.18 \\
\hline 11. & Student can ask the question to lecturer after getting their marks. & 0.17 \\
\hline 12. & Student conduct the brainstorming activity on their work. & 0.17 \\
\hline 13. & Lecturer motivated the student to be more creativity. & 0.16 \\
\hline 14. & Lecturer always follow and track student assignment. & 0.15 \\
\hline 15. & Student exchange the opinion via social network. & 0.15 \\
\hline 16. & Student can study over the internet. & 0.13 \\
\hline 17. & Student can choose their own interest on the study topic. & 0.13 \\
\hline 18. & Lecturer has reasonable criteria for evaluation. & 0.12 \\
\hline 19. & The exams are suitable for the student. & 0.12 \\
\hline 20. & The Lecturer always conduct formative evaluation. & 0.12 \\
\hline
\end{tabular}

From the TABLE II shown that the most critical issue that need to be improve before implementing the $\mathrm{u}$ learning system is the internet connectivity $(\mathrm{PNI}=0.33)$. The other critical requirement indicated that the students need a pedagogical method that let them freely learn anytime, anywhere $(\mathrm{PNI}=0.24)$. They also need a different teaching method to improve their learning and able to access to the internet resources anytime (PNI = 0.23 ), while they can personally learn what they want before entering the class $(\mathrm{PNI}=0.22)$. For the reviewing their lesson they also need learning materials especially video lecture $(\mathrm{PNI}=0.21)$, and they need an activity to discuss together $(\mathrm{PNI}=0.20)$. The results indicate that the student needs strongly consist with the flipped classroom pedagogy.

4) More than half of the participant preferred to prepare themselves by reading and watching the learning material that lecturer provide to them and conclude the information follow the topic listed by their lecturer before the class begin $(\mathrm{N}=171,62.41 \%)$, while nearly half of them preferred to seeking the information that related to the topics listed by the lecturer $(\mathrm{N}=108,39.42 \%)$. In contrast, they are rarely preferred to search the information for doing a quiz before the class begin $(\mathrm{N}=72,26.28 \%)$. The result indicated that lecturer should offer the learning material for the student with the guiding question to prepare themselves before the class start.

5) Half of the participant preferred the learning activity that they can practice under the guidance of lecturer with immediately feedback $(\mathrm{N}=137,50 \%)$, while almost half of them preferred the discussion and 
cooperatively conclude the lesson $(\mathrm{N}=107,39.05 \%)$, equal the activity that they can validating and expanding the knowledge together $(\mathrm{N}=107,39.05 \%)$. This indicated that students need the meaningful learning activities, so the active learning strategy should be applied.

6) More than half of the participant preferred handout as a learning material $(\mathrm{N}=184,67.15 \%)$, while nearly half of them preferred internet resources $(\mathrm{N}=134,48.91 \%)$ and lecturer made videos $(\mathrm{N}=113,41.24 \%)$. In opposite, local learning resources and e-book are less preferred among agricultural students $(\mathrm{N}=23,8.39 \%$, $\mathrm{N}=67,24.45 \%$ ). The students mostly preferred to receive their learning material via Facebook or lecturer's website $(\mathrm{N}=191,69.71 \%)$ and give to them directly $(\mathrm{N}=145,52.92 \%)$, but less of them preferred to receive via email $(\mathrm{N}=79,28.83 \%)$.

7) The most preferable classroom material are presentation $(\mathrm{N}=210,76.64 \%)$, Virtual Reality (VR) or Interactive Multimedia $(\mathrm{N}=126,45.99 \%)$, and Websites $(\mathrm{N}=101,36.86 \%)$, while the most preferable communication tools are Facebook $(\mathrm{N}=253,92.34 \%)$ and Line $(\mathrm{N}=251,91.61 \%)$.

\subsection{Further Research}

This study has undertaken to identifying agricultural students' need for u-learning based on flipped classroom concept. The results will be used during the second phase of the research which involves the design and implementation of u-learning model based on flipped classroom concept at Agricultural Technology Faculty, KMITL. For better understanding, the future studies should include exploring lecturers' perspectives toward ulearning model, will provide a useful information to develop the u-Learning model.

\section{References}

[1] B. de Sousa Monteiro, A. S. Gomes, and F. M. Mendes Neto, "Youubi: Open software for ubiquitous learning," Computers in Human Behavior, vol. 55, pp. 1145-1164, February 2016.

https://doi.org/10.1016/j.chb.2014.09.064

[2] C. Lombardini, M. Lakkala, and H. Muukkonen. (February 2018). The impact of the flipped classroom in a principles of microeconomics course: evidence from a quasi-experiment with two flipped classroom designs. International Review of Economics Education, [Online]. Available: https://doi.org/10.1016/j.iree.2018.01.003

[3] C. Sojayapan and J. Khlaisang. (February 2018). The effect of a flipped classroom with online group investigation on students' team learning ability. Kasetsart Journal of Social Sciences, [Online]. Available: https://doi.org/10.1016/j.kjss.2018.02.003

[4] F. Faul, E. Erdfelder, A. G. Lang, and A. Buchner, "G*Power 3: A flexible statistical power analysis program for the social, behavioral, and biomedical sciences," Behavior Research Methods, vol. 39, pp. 175-191, May 2007.

https://doi.org/10.3758/BF03193146

[5] L. A. Cárdenas-Robledo and A. Peña-Ayala. (January 2018). Ubiquitous learning: A systematic review. Telematics and Informatics, [Online]. Available: https://doi.org/10.1016/j.tele.2018.01.009

[6] M. Inthachot, S. Sopeerak, and N. Rapai, "The Development of a U-learning Instructional Model Using Project based Learning Approach to Enhance Students' Creating-innovation Skills," Procedia - Social and Behavioral Sciences, vol. 103, pp. 1011-1015, November 2013.

https://doi.org/10.1016/j.sbspro.2013.10.426

[7] P.-S. Tsai, C.-C. Tsai, and G.-H. Hwang, "College students' conceptions of context-aware ubiquitous learning: A phenomenographic analysis," The Internet and Higher Education, vol. 14, pp. 137-141, July 2011.

https://doi.org/10.1016/j.iheduc.2011.01.004 